\title{
Is Anyone Listening? The Legal Marginalization OF HEARING DisAbILITIES
}

\author{
BRENDAN W. WILLIAMS*
}

Hearing impairment is a common disability. According to the National Institute on Deafness and Other Communication Disorders, as many as 3 babies out of 1,000 born in the United States have detectable hearing loss. ${ }^{1}$ As one ages, the chances of hearing loss increase. ${ }^{2}$ Roughly $2 \%$ of those aged forty-five to fifty-four have a disabling hearing loss, a rate that grows to $8.5 \%$ of those aged fifty-five to sixty-four; almost one-quarter of those aged sixty-five to seventyfour; and half of those seventy-five and older. ${ }^{3}$

Yet for the millions of Americans who might benefit from hearing aids-28.8 million adults, as of a 2016 calculation-relatively few will use them. ${ }^{4}$ That includes only $16 \%$ of those aged twenty to sixty-nine who could benefit. ${ }^{5}$

In most states, health insurance is not required to cover hearing aids, or even hearing exams. Those states that do have hearing aid insurance mandates tend to confine them to children. ${ }^{6}$ Twenty-two states have such a requirement. ${ }^{7}$ Only four states-Arkansas, Connecticut, New Hampshire, and Rhode Island-require coverage for hearing aids for both children and adults. ${ }^{8}$

Hearing aids are very expensive, ranging from $\$ 900$ to $\$ 3,500$ or more per ear. ${ }^{9}$ Without insurance, that cost must be born out-of-pocket. Yet, according to a May 2018 report from the Federal Reserve, "[f]our in ten adults, if faced with an unexpected expense of $\$ 400$, would either not be able to cover it or would cover it by selling something or borrowing money." 10

Given the correlation between aging and hearing loss, one might expect

* Attorney Brendan Williams is a nationally-published writer on health care and civil rights issues. M.A., Washington State University; J.D., University of Washington School of Law. This article is dedicated to audiologists, overwhelmingly-women, who are too often as marginalized as their patients.

1. Nat'l Inst. on Deafness \& Other Comms. Disorders, Quick Statistics About Hearing, NAT'L INSTS. HEALTH (Dec. 15, 2016), https://www.nidcd.nih.gov/health/statistics/quick-statisticshearing [https://perma.cc/5CKX-U453].

2. Id.

3. $I d$.

4. $I d$.

5. Id.

6. State Insurance Mandates for Hearing Aids, AM. SPEECH-LANGUAGE-HEARING Ass'N, https://www.asha.org/advocacy/state/issues/ha_reimbursement/ [https://perma.cc/6LEU-4ULP].

7. Id. Wisconsin also requires that health plans cover children's cochlear implants. Id.

8. Id.

9. Karen Weintraub, Why Are Hearing Aids So Expensive?, N.Y. Times (Oct. 20, 2017), https://www.nytimes.com/2017/10/20/well/live/why-are-hearing-aids-so-expensive.html [https://perma.cc/XV7Z-JUF4].

10. Federal Reserve Board Issues Report on the Economic Well-Being of U.S. Households, FEDERAL RESERVE (May 22, 2018), https:/www.federalreserve.gov/newsevents/pressreleases/ other20180522a.htm [https://perma.cc/GM4Q-B39U]. 
Medicare to cover hearing aids. It does not. Indeed, Medicare does not even proactively cover hearing exams, although bipartisan legislation has been introduced in the U.S. Senate to require at least that much through allowing selfreferred visits to audiologists. ${ }^{11}$

The consequences of untreated hearing disabilities for the elderly can be severe. As one article notes, "[1] osing the ability to hear well doesn't just mean people have to turn the volume way up on their favorite TV shows. Hearing loss is associated with depression, social isolation and an increased risk for cognitive decline and dementia in older adults." ${ }^{\prime 2}$ found:

That might create significant additional costs. As one study reported in 2014

Although the brain becomes smaller with age, the shrinkage seems to be fast-tracked in older adults with hearing loss, according to the results of a study by researchers from Johns Hopkins and the National Institute on Aging. The findings add to a growing list of health consequences associated with hearing loss, including increased risk of dementia, falls, hospitalizations, and diminished physical and mental health overall. ${ }^{13}$

United States Representative Debbie Dingell (D., Mich.) has sponsored a bill requiring Medicare to cover hearing aids, but the Medicare Hearing Aid Coverage Act of 2017, with only eight Democratic co-sponsors, had received no committee hearing through July 2018. ${ }^{14}$

The rate of bankruptcy among those 65-and-older is at an all-time high, and, according to a study of those filing for bankruptcy, "[a]bout three in five said unmanageable medical expenses played a role." ${ }^{15}$ Faced with financial exigency,

11. Michelle Andrews, Can You Hear Me Now? Senate Bill Aims to Broaden Access to Hearing Services., KaISER HeAlth News (Apr. 10, 2018), https://khn.org/news/can-you-hear-menow-senate-bill-on-hearing-aids-may-make-the-answer-yes/ [https://perma.cc/Y5ZT-9Y8F].

12. Id.

13. Hearing Loss Linked to Accelerated Brain Tissue Loss, JoHn Hopkins Med. (Jan. 22, 2014), https://www.hopkinsmedicine.org/news/media/releases/hearing_loss_linked_to_accelerated_ brain_tissue_loss_[https://perma.cc/4FGR-XLT9].

14. See Medicare Hearing Aid Coverage Act of 2017, H.R. 3426, $115^{\text {th }}$ Cong. (2017). In a 2012 column, one woman wrote, "it came as a shock to me and I'm sure millions of others to realize that the extremely common need for hearing aids wasn't being met by the safety net for seniors." Ann Brenoff, Why Medicare Should Pay For Hearing Aids, Huffington Post (Oct. 23, 2012, 1:49 PM), https://www.huffingtonpost.com/ann-brenoff/say-what-aboutmedicare_b_1954229.html [https://perma.cc/A8WB-V4L2]. Of her then 77-year-old husband, she stated:

I can only speak from example when I say: No single health issue has impacted my family's life as much as my husband's loss of hearing. Nope, not even his heart attack and open heart surgery - which, while terrifying at the time, were the wakeup call we needed to launch a healthier lifestyle that includes diet and exercise.

Id.

15. Tara Siegel Barnard, 'Too Little Too Late': Bankruptcy Booms Among Older Americans, 
many seniors will obviously choose to forgo the out-of-pocket cost of hearing aids.

The cost of adding hearing aid coverage to Medicare is also unlikely to appeal to fiscal hawks, especially with some, including outgoing House Speaker Paul Ryan (R., Wis.), blaming "entitlement programs"-not tax cuts-for the federal deficit. ${ }^{16}$

What is especially incongruous is that Medicare's parsimony regarding hearing aids does not apply to all durable medical equipment, including, most notoriously, the motorized scooters and wheelchairs that have been at the center of fraud claims.

As a 2014 Washington Post investigation reported, "[s]ince 1999, Medicare has spent $\$ 8.2$ billion to procure power wheelchairs and 'scooters' for 2.7 million people. Today, the government cannot even guess at how much of that money was paid out to scammers."17

Compare this to the fact that a 2018 Commonwealth Fund report found that "[a]mong Medicare beneficiaries, 75 percent of people who needed a hearing aid did not have one." 18

At the state level, the challenge is overcoming the health insurance lobby, which loathes insurance mandates (if not, ironically, the former federal mandate that one have insurance). ${ }^{19}$ In a National Review column, Kevin Williamson

N.Y. TimeS (Aug. 5, 2018), https://www.nytimes.com/2018/08/05/business/bankruptcy-olderamericans.html [https://perma.cc/T7S7-BLCA].

16. See, e.g., Nathaniel Weixel, Ryan Eyes Push for 'Entitlement Reform' in 2018, THE HILL (Dec. 6, 2017, 5:24 PM), http://thehill.com/homenews/house/363642-ryan-pledges-entitlementreform-in-2018 [https://perma.cc/4PML-8869].

17. David Fahrenthold, A Medicare Scam That Just Kept Rolling, Wash. Post (Aug. 16, 2014), https://www.washingtonpost.com/sf/national/2014/08/16/a-medicare-scam-that-just-keptrolling/?utm_term=.263b2ab7da43 [https://perma.cc/Y98G-HBAZ]. Though, in other instances where people have needed wheelchairs, insurers have refused to provide them. See Jason Clayton, Iowa Medicaid Company Forced to Provide Special Wheelchairs to Disabled Clients, Des MoINES REG. (Aug. 20, 2018, 6:48 PM), https:/www.desmoinesregister.com/story/news/investigations/ 2018/08/20/provide-them-wheelchairs-judges-tell-iowa-medicaid-company/976986002/ [https://perma.cc/TH6H-CSDF] (explaining that "appeals by UnitedHealthcare - each involving a severely disabled Iowan who can't walk independently-lingered for more than a year while the managed care provider denied doctor and state orders that it pay for the specialized equipment.").

18. Amber Willink et Al., How Medicare Could Provide Dental, Vision, and Hearing Care for Beneficiaries, Commonwealth Fund, Jan. 18, 2018, at 1, https://www.commonwealthfund. org/publications/issue-briefs/2018/jan/how-medicare-could-provide-dental-vision-and-hearing-care [https://perma.cc/G9KJ-QP5L].

19. A 1997 brief from the conservative Heritage Foundation asserts, "[b]y singling out mastectomies or maternity care, politicians grant favored status to those suffering from a particular disease or disability, often responding to organized pressure rather than to medical priorities". Carrie Gavora, How Health Insurance Mandates Misdiagnose the Disease, Heritage FOUNDATION (1997), https:/www.heritage.org/health-care-reform/report/how-health-insurancemandates-misdiagnose-the-disease [https://perma.cc/B6DC-BP7Y]. 
argued against a 2017 proposal in Texas to mandate insurance coverage of children's hearing aids: "[i]n the case of an insurance company, the expense of a new mandate might be passed along in the form of higher monthly premiums, or it might be passed along in the form of less generous coverage for other expenses. ${ }^{20}$ His opposition was in vain. ${ }^{21}$

An extreme example of deference to the insurance lobby occurred in the progressive state of Washington. There a Republican state senator, Barbara Bailey, introduced a bill to require hearing aid coverage for state employees and those on Medicaid..$^{22}$ It passed into law in 2018. ${ }^{23}$

According to a press release from the new law's prime sponsor:

"Medicaid stopped covering hearing aids in 2011, and this is a longoverdue fix," said Bailey, R-Oak Harbor. "This is about access and affordability for those suffering from hearing loss, which can mean all the difference. This law will not only help aging populations who are hard of hearing, but also low-income adults and children who may be struggling to succeed in class without access to hearing aids." ${ }^{24}$

Yet the new law creates a paradox, in that those who have private insurance have no statutory right to hearing aids, or even hearing exams. A Senate floor amendment offered to the bill during its 2017 consideration would have rectified this for children on private health insurance:

Each health benefit plan entered into, or renewed on or after January 1, 2018, shall include coverage for hearing aids for children under the age of eighteen when medically necessary. Coverage must include a new hearing aid every five years, a new hearing aid when alterations to the existing hearing aid cannot meet the needs of the child, and services and supplies such as the initial assessment, fitting, adjustment, and auditory training. ${ }^{25}$

20. Kevin D. Williamson, Mandates Are Government Benefits in Disguise, NAT'L REV. (Mar. 14, 2017, 6:10 PM), https:/www.nationalreview.com/corner/there-no-such-thing-free-hearing-aideven-texas/ [https://perma.cc/UK52-3R9P] (statement of Rep. Rodney Anderson) (illustrating that "if we are going to use government, then, by all means, let's use government in the most honest, transparent, and straightforward way we can. Forget the insurance mandate and just write the check." Id. But should that argument apply to all state insurance mandates; e.g., mammograms?).

21. See Rep. Rodney Anderson, A Win for Texas Children: Children's Hearing Aid Bill Signed Into Law, Tex. House Representatives (June 15, 2017), https:/house.texas.gov/ news/press-releases/?id=6315 [https://perma.cc/UXW6-4X5C].

22. S.B. $5179,65^{\text {th }}$ Leg., Reg. Sess. (Wash. 2017).

23. 2018 Wash. Sess. Laws 827.

24. Governor Signs Duo of Bailey Health-Care Bills into Law, SEnator Barbara Bailey - RePUBLICAN WHIP (Mar. 22, 2018), http://barbarabailey.src.wastateleg.org/governor-signs-duobailey-health-care-bills-law/ [https://perma.cc/NP3C-XDV3].

25. Wash. S. Amend. 79 to 2S.S.B. 5179 (not adopted Mar. 6, 2017), http://lawfilesext. leg.wa.gov/biennium/2017-18/Pdf/Amendments/Senate/5179-S2\%20AMS\%20VAND\% 
The amendment was defeated on a 25-24 vote, and no effort was made to reintroduce the amendment during the bill's successful 2018 passage. ${ }^{26}$

Why are we balking at requiring insurers to pay for hearing aids? For a comparison, though obesity is largely preventable, state insurance regulators require health insurers to cover a host of costs related to it. And those costs are not inconsiderable. For example, as one 2015 study notes, "[w] hile not every overweight/obese individual has diabetes, some $80 \%$ of those with diabetes are overweight/obese." ${ }^{27}$ The study estimates that roughly $21 \%$ of all health care expenditures in the United States are obesity-related. ${ }^{28}$ Another study, published in 2016, relates that "[i]n addition to the health consequences of obesity, the yearly economic impact of adult obesity in the U.S. has been estimated at over $\$ 315$ billion in direct medical costs alone." ${ }^{29}$

Yet we are doing little to prevent this epidemic. Instead, one article relates: "More sugary chocolate milk, fewer whole grains, and around 300 extra milligrams of salt - these are just some of the ways the Trump Administration has relaxed school-lunch nutrition rules put in place during the Obama Administration." ${ }^{30}$ This deregulation has occurred despite the fact that "[m]ore than half of US children in school today are on track to be obese by age 35."

No responsible policymaker is suggesting that health insurance not cover the costs associated with obesity. Indeed, obesity has given rise to a common insurance mandate. According to a 2016 analysis from the National Conference of State Legislatures, " 23 states now have a specific health benefit requirement to cover bariatric or gastric bypass surgery, which reduces the physical size of a patient's stomach and the urge to over-eat." ${ }^{.32}$

The federal tax bill signed into law in December 2017 provided a major tax cut for alcohol producers - a cut that the leading Democrat on the Senate Finance

20NEED\%20221.pdf [https://perma.cc/HS9E-EZF2].

26. See Roll Calls on a BILl, S.B. 5179, S. Reg. Sess. (Wash. 2017), http://app.leg.wa.gov/ $\mathrm{dlr} /$ rollcall/rollcall.aspx?bienid=24\&legnum=5179 [https://perma.cc/338Q-MRD8].

27. Adela Hruby \& Frank B. Hu, The Epidemiology of Obesity: A Big Picture, 33 Pharmacoeconomics 7, 10 (2015).

28. Id. at 12 .

29. Julie J. Kim et al., ASMBS Updated Position Statement on Insurance Mandated Preoperative Weight Loss Requirements, 12 SURGERY FOR OBESITY AND RELATED DISEASES 955, 955 (Apr. 18, 2016).

30. Hilary Brueck, Kids Are Eating Less Whole Grains and More Sugary Milk in School Lunches This Year, Business INSIDER (Jan. 11, 2018, 1:54 PM), https://www.businessinsider. com/trump-administration-relax-school-lunch-rules-2018-1\#since-the-2014-2015-school-yearcafeterias-across-the-country-were-required-to-serve-kids-whole-grain-rich-meals-but-notanymore-1 [https://perma.cc/XA2W-2PV2].

31. Id.

32. Richard Cauchi, Most States Have Expanded Health Insurance Coverage for Treatment of Obesity; Some Target Obesity, NAT'L CONF. OF ST. LEGIS. (Mar. 1, 2016), http://www.ncsl.org/ research/health/aca-and-health-mandates-for-obesity.aspx [https://perma.cc/UA3S-V75T]. 
Committee is pushing to make permanent. ${ }^{33}$ Consider the costs of this bipartisanship. An estimated 88,000 Americans a year die from excessive drinking. ${ }^{34}$ One study found that in the United States, "[c]irrhosis-related deaths increased by 65 percent from 1999 to 2016, and deaths from liver cancer doubled, the study said. The rise in death rates was driven predominantly by alcoholinduced disease, the report said." ${ }^{35}$

No responsible policymaker is suggesting that health insurance not cover the costs associated with alcohol misuse. So why are the costs associated with hearing disability not worth socializing?

In a 2009 report, the Council for Affordable Health Insurance, an organization comprised of many insurance company members and organizations representing those providing employer-subsidized health insurance, ${ }^{36}$ took issue with insurance mandates and offered many of the traditional arguments against them. ${ }^{37}$ The authors wrote:

Mandating benefits is like saying to someone in the market for a new car, if you can't afford a Cadillac loaded with options, you have to walk. Having that Cadillac would be nice, as would having a health insurance policy that covers everything one might want. But drivers with less money can find many other affordable car options; whereas when the price of health insurance soars, few other options exist. ${ }^{38}$

They stated, "[t]he question that every legislator needs to ask is: When does one person's or group's need to have some new or traditionally uncovered procedure or therapy paid for by health insurance outweigh the majority's need to keep premiums affordable?" 39 However, even they quantified the cost of

33. Naomi Jagoda, Alcohol Industry Pushes Lawmakers to Uncork Excise Tax Relief, THE HILL (May 16, 2018), http://thehill.com/business-a-lobbying/387874-alcohol-industry-pusheslawmakers-to-uncork-excise-tax-relief [https://perma.cc/ZHH3-LTED].

34. Joel Achenbach, A Huge Clinical Trial Collapses, and Research on Alcohol Remains Befuddling, THE WASH. Post (Aug. 5, 2018), https://www.washingtonpost.com/national/healthscience/a-huge-clinical-trial-collapses-and-research-on-alcohol-remains-befuddling/ 2018/08/03/d5205bd8-749a-11e8-805c-4b67019fcfe4_story.html?utm_term=.246aa281e47a [https://perma.cc/J4C4-WUYU].

35. Kate Furby, Alcohol-Related Liver Deaths Have Increased Sharply, THE WASH. PosT (July 18, 2018), https:/www.washingtonpost.com/news/to-your-health/wp/2018/07/18/alcoholrelated-liver-deaths-have-increased-sharply/?utm_term $=.381 \mathrm{dc} 791 \mathrm{cc} 37 \quad[\mathrm{https}: / /$ perma.cc/29SN$\mathrm{U} 82 \mathrm{G}]$.

36. See Our Members, Council for Affordable Health Coverage, https://www.cahc. net/our-members [https://perma.cc/Z3CP-6JG9].

37. See Victoria Craig Bunce \& JP Wieske, Health Insurance Mandates in the States 2009, Council For Affordable Health Ins. (2009), https://www2.cbia.com/ieb/ag/CostOfCare/ RisingCosts/CAHI_HealthInsuranceMandates2009.pdf [https://perma.cc/8C5L-NPP4].

38. Id. at 1 .

39. Id. at 3 . 
hearing aid coverage for minors as negligible-less than $1 \%$ of premium cost. $^{40}$

To be sure, some caution with respect to insurance mandates is not unreasonable. For example, in 2011 the Washington Senate passed a bill innocently entitled "AN ACT Relating to insurance coverage of tobacco cessation treatment in the preventative benefit required under the federal law." ${ }^{41}$ Not so innocently, the bill was pushed by Pfizer Inc. ${ }^{42}$ which makes the drug Chantix a drug known at the time to have the serious side effect of suicidal ideation. ${ }^{43}$ Pfizer went on to pay over $\$ 300$ million in lawsuit settlements. ${ }^{44}$ And Pfizer itself reported in 2018 that Chantix was ineffective in smoking cessation efforts aimed at adolescents. ${ }^{45}$

Yet the science behind the efficacy of hearing aids would appear to be incontrovertible. Evidence shows that children with even unilateral (one ear) uncorrected hearing loss "had lower language and verbal IQ scores than their siblings with normal hearing." ${ }^{46}$ They "are at risk for delays in speech-language development, cognition, and behavioral problems that can affect functioning at school." 47

The most recent states to enact hearing aid insurance mandates were Georgia and Texas in 2017. Reporting on the debate over the two bills is instructive.

In Georgia, the law is formally known as "The Hearing Aid Coverage for Children Act."" More informally, it is known as "Jack's Law," named - according to a news article - after "Georgia teen Jack McConnell, 15, who was the first Georgia baby identified with hearing loss after the passage of newborn hearing legislation in 1999." ${ }^{49}$ According to that article, children were

40. See id. at 5 .

41. S.B 5039, $62^{\text {nd }}$ Leg., Reg. Sess. (Wash. 2011).

42. See State of Washington, S. Comm. Health \& Long-Term Care, S.B. Rep. S.B. 5039, at 3 (Feb. 7, 2011).

43. See Lilly Fowler, Quitting Smoking Can Be Dangerous to Your Health, Mother Jones (Dec. 15, 2010, 11:00 AM), https://www.motherjones.com/politics/2010/12/quit-smoking-chantixsuicide-pfizer-fda [https://perma.cc/XYD9-YE43].

44. Todd C. Frankel, Pill That Quashes Tobacco Urge Found in Plain Sight, THE Wash. Post (May 15, 2015), https://www.washingtonpost.com/business/economy/pill-promises-a-safercheaper-way-than-chantix-to-quit-smoking/2015/05/15/8ce5590c-f830-11 e4-9030b4732caefe81_story.html?utm_term=.36c0aa4e67d7 [https://perma.cc/X3LT-NVE2].

45. Pfizer's quit-smoking Chantix Fails Study in Adolescent Smokers, REUTERS (Mar. 23, 2018, 8:29 AM), https:/www.reuters.com/article/us-pfizer-chantix/pfizers-quit-smoking-chantixfails-study-in-adolescent-smokers-idUSKBN1GZ1R9 [https://perma.cc/M7S5-FRW4].

46. J. E. C. Lieu, Unilateral Hearing Loss in Children: Speech-Language and School Performance (Apr. 1, 2015), https://www.ncbi.nlm.nih.gov/pmc/articles/PMC4382076/ [https:// perma.cc/45NE-JN62].

47. Id.

48. Ga. Code ANN. § 33-24-59.21(2018).

49. Jennifer Leslie, Children's Hearing Aid Bill Becomes Law in Georgia, 11ALIVE.COM (May 9, 2017, 6:11 AM) https://www.11 alive.com/article/news/childrens-hearing-aid-bill-becomeslaw-in-georgia/438035286 [https://perma.cc/LA94-VXLY]. 
"already covered by Medicaid and were added to the State Health Benefit Plan, which covers 650,000 state employees, in 2015. ${ }^{\circ 0}$ The expense turned out to be far less than anticipated, and, based upon this cost experience, a parent advocating the new hearing aid mandate stated it would "cost less than 3-cents per insured individual per month." 51

The Georgia's law's intent section takes note of the science of hearing aids:

The General Assembly finds and declares that:

(1) The language development of children with partial or total hearing loss may be impaired due hearing loss. Children learn the concept of spoken language through auditory stimuli, and the language skills of children who have hearing loss improve when they are provided with hearing aids and access to visual language upon the discovery of hearing loss; and

(2) Providing hearing aids to children with hearing loss will reduce the costs borne by this state, including special education, alternative treatments that would otherwise be necessary if a hearing aid were not provided, and other costs associated with such hearing loss. ${ }^{52}$

The law also expressly addresses the issue of cost associated with hearing aids, exempting from the mandate any insurer for which actuarial analysis certifies, to satisfaction of the state's insurance commissioner, that

the costs associated with coverage of children's hearing aids required under this Code section, and not covered as of January 1, 2019, exceeded 1 percent of the premiums charged over the experience period by the insurer, corporation, or health maintenance organization; and

(B) Such costs solely would lead to an insurance in average premiums charged of more than 1 percent for all insurance policies, subscription contracts, or health care plans commencing on inception or the next renewal date, based on the premium rating methodology and practices the insurer, corporation, health maintenance organization, or governmental entity employs[.] $]^{53}$

Based upon the Council for Affordable Health Insurance analysis, ${ }^{54}$ those cost triggers would not appear to be at risk.

Georgia's law is one of the nation's most generous, providing "coverage for the billed charges of one hearing aid per hearing impaired ear not to exceed

50. Id.

51. Id.

52. GA. Code ANN. § 33-24-59.21(b) (2018).

53. Id.

54. Bunce \& Wieske supra note 37. 
$\$ 3,000.00$ per hearing aid for covered individuals 18 years and under." ${ }^{55}$ These can be replaced every four years at insurer cost. ${ }^{56}$ Georgia is even progressive enough to provide hearing aids to those children who are uninsured and not covered by Medicaid. A February 2018 article reported:

So if your child isn't insured through private insurance and you don't qualify for Medicaid where do you go? If you're caught in the middle here, well, the state has you covered.

The vice chair over at the Public Service Commission says new rules mean more children and adults will have access to hearing aids through the state's hearing aid distribution program. ${ }^{57}$

In Texas, the prime sponsor of the 2017 children's hearing mandate had previously introduced such legislation in 2015. At that time a mother's advocacy was reported:

"Progressive hearing loss means he will continue to lose little hearing, and eventually he'll be deaf," Chrystal Smith said about her 6-year-old son Daniel.

And keeping up with a bag full of supplies can add up. By the time Daniel is 18 , she expects to pay more than $\$ 40,000$ out of pocket.

"That doesn't include the equipment, the battery, the cleaning, the audiologist, the ENT, the speech therapy, and all of that," said Smith.

Texas does not require her insurance to cover hearing aids, like it does for glasses.

"We should be saving for college, we're saving for hearing aids," said Smith. ${ }^{58}$

Of the prime sponsor, Representative Rodney Anderson, the Dallas Morning News editorialized: "During the 2017 legislative session in Austin, the title insurance executive from Grand Prairie impressively rallied support to change the insurance code to stop insurance companies from denying coverage for hearing aids and cochlear implants to children."59 The Republican's bill was

55. GA. Code ANN. § 33-24-59.21(d) (2018).

56. Id.

57. Dana Fowle, State Expands Hearing Aid Distribution Program, FOX5ATLANTA (Feb. 13, 2018, 5:54 PM), http://www.fox5atlanta.com/news/i-team/state-expands-hearing-aiddistribution-program [https://perma.cc/3C5K-N2B6].

58. Phil Prazan, Texas Lawmakers Debate Coverage for Child Hearing Aids, KXAN (May 5, 2015, 6:37 PM), https://www.kxan.com/news/texas-lawmakers-debate-coverage-for-child-hearingaids_20180316011616777/1049568887 [https://perma.cc/D9BU-BRKF].

59. We Recommend Rodney Anderson in the GOP Primary for State House District 105, 
opposed by a conservative organization, Empower Texas, which scored it as antitaxpayer.$^{60}$ Despite this opposition, it still passed the Republican House by almost a 6-to1 margin. ${ }^{61}$

The most generous prescribed insurance mandate is that of Oregon, which applies to children under 18, and up to the age of 25 (if "enrolled in a secondary school or an accredited educational institution"), with a cost of up to $\$ 4,000$ "for one hearing aid per hearing impaired ear" required under statute before inflationadjustment upward began in $2010 .^{62}$ Insurers are required to cover replacements every four years. ${ }^{63}$

In contrast, Connecticut law limited the benefit to $\$ 1,000$ every two years to children twelve and younger. ${ }^{64}$ In a 2015 bulletin, the Connecticut Insurance Department deemed the age limit discriminatory; "the Insurance Department has reviewed the age limit of 12 and under and has determined hearing aids may be clinically effective for all ages, and is therefore requiring carriers to remove the age limits on hearing aid benefits for policies issued or renewed on or after January 1, 2016." ${ }^{65}$

Although this determination was based upon the Affordable Care Act ${ }^{66}$ no other state insurance regulator has followed suit.

Arkansas law is perhaps the most generous with respect to coverage of hearing aids for both children and adults, mandating coverage of hearing aids of up to $\$ 1,400$ cost per ear, every three years ${ }^{67}$ In contrast, for children and adults, New Hampshire mandates coverage of hearing aids of up to $\$ 1,500$ cost per ear, but only every five years, ${ }^{68}$ while Rhode Island mandates coverage for hearing aids of up to $\$ 1,500$ cost per ear for children up to nineteen-years-old, every three years, but only up to $\$ 700$ for adults per ear, every three years. ${ }^{69}$

There would appear to be no political cost to siding with children in requiring

Dallas Morning News (Jan. 21, 2018), https://www.dallasnews.com/opinion/editorials/2018/ 01/21/recommend-rodney-anderson-gop-primary-state-housedistrict-105 [https://perma.cc/B7939FMB].

60. See HB 490: Creating a New Hearing Aid/Cochlear Implant Insurance Mandate, EMPOWERTEXANS, https://index.empowertexans.com/votes/2017-house-vote-rv385, [https://perma.cc/RT2F-HAVX].

61. Id. The Texas insurance mandate for children's hearing aids does not specify a dollar limit, though it expressly does allow for "deductibles" and "coinsurance" payments out-of-pocket. See TEX. Ins. Code ANN. § 1367.253(d) (2018).

62. OR. REV. STAT § 743A.141 (2017).

63. See id.

64. Conn. Gen. Stat. § 38a-490b (2018).

65. State of Conn. Ins. Dep't, Bulletin HC-102, Health Insurance Coverage For Hearing Aids-Conn. Gen. Stat. § 38A-490B AND § 38A-516B (2015), https://www.ct.gov/ cid/lib/cid/HC-102.pdf [https://perma.cc/BXS2-UXYJ].

66. See id.

67. ARK. CODE ANN. § 23-79-1402 (2018).

68. N.H. REV. STAT. ANN. § 415:6-p (2018).

69. 27 R.I. GEN. LAWS $§ 18-60$ (2018). 
insurance companies to cover hearing impairment. In Tennessee, a Republican state senator, after successfully pushing a hearing aid mandate for children into law, was attacked in his 2012 re-election campaign by a primary challenger who accused him of "raising the cost of health insurance by millions of dollars statewide." ${ }^{\prime 70}$ The incumbent, who had also supported unsuccessful bariatric surgery mandates, responded:

I think what it reflects was just pennies on premiums. ... Once they have hearing aids, these children can go to school and keep up with their classmates and graduate high school with their cohort. What we are talking about is improving children's lives and helping to make them productive citizens. ${ }^{71}$

The attacks were unsuccessful. ${ }^{72}$

The greater risk would appear to be a loss of political contributions from health insurance companies. Fear of riling the insurance industry can lead to odd results, like Washington's new hearing aid law conferring rights upon children on Medicaid, and children of state employees, that children on private insurance do not enjoy. For the 2016 election in the state of Washington, for example, Premera Blue Cross gave $\$ 241,320$ between political candidates for state office and committees. ${ }^{73}$

In the face of such giving, kids are not much of a barrier. In opposing a

70. Joel Davis, Hughes: Overbey Dishonest on Voting Record, DAILY TIMEs (June 26, 2012), https://www.thedailytimes.com/news/hughes-overbey-dishonest-on-votingrecord/article_560c9d5c-db80-514f-9e9c-f793ec3e7659.html [https://perma.cc/VWK2-A4PB].

71. Id.

72. In 2017, the mandate's prime sponsor, David Overbey, still a state senator, was unanimously confirmed by the U.S. Senate as a U.S. attorney. See Overbey Follows Proud Tradition of United States Attorneys, DAILY Times (Nov. 12, 2017), https://www.thedailytimes. com/opinion/our_voice/overbey-follows-proud-tradition-of-united-statesattorneys/article_9c0f149e-2d5d-54bd-b8c0-eb402b45a669.html [https://perma.cc/GQ4R-S3M8].

73. See Contributions, Pub. Disclosure Commission, https://www.pdc.wa.gov/browse/ more-ways-to-follow-the-money/advanced-search/contributions?category=Advanced $\% 20$ Search (enter "Premera" in contributor data field and "2016" in election year data field) (last visited Oct. 6, 2018). As a story in the Puget Sound Business Journal once related, "On the chessboard of Olympia politics, Premera is a queen: nimbly moving in every direction, knowing when to strike and outmaneuvering opponents of all kinds." Valerie Bauman, Premera's Power Politics, PUGET Sound Bus. J. (Apr. 4, 2014), https://stateofreform.com/wp-content/uploads/2014/07/PremeraPower-Politics.pdf [https://perma.cc/3RFF-ZA6X]. E-mail from Sheila Tallman, Senior Manager, Premera Blue Cross, to Christine Rolfes, Senator, Washington Senate (Jan. 21, 2016, 20:54 PST) (on file with author). In Washington, the state's elected insurance commissioner did not require insurers to provide autism benefits to children until a unanimous Washington Supreme Court decision; in a suit brought against an insurer, the court directed the commissioner to do so under the plain meaning of long-existing statute. See O.S.T. ex rel. v. BlueShield, 335 P.3d 416, 421 n.9 (Wash. 2014) ("Regence BlueShield's exclusion was contrary to the plain language of the mental health parity act, and OIC's action (or inaction) is irrelevant."). 
previous, stand-alone hearing aid mandate effort, Premera had argued, "In WA state, hearing aids are not specifically included in the Essential Health Benefits categories and not included in the benchmark plan." In other words, benefits should not exceed the "floor" promulgated under the Affordable Care Act. ${ }^{74}$

Pediatric hearing mandate legislation has died even in California, known as a bastion of liberalism, ${ }^{75}$ after insurance company opposition. Most recently, Assembly Bill $1601,{ }^{76}$ introduced in 2017, had the support of a range of groups, including the California Children's Hospital Association, the California Teachers Association, and others. ${ }^{77}$

Fatefully, however, AB 1601 was opposed by the insurance industry; according to a summary of their opposition "health benefit mandates stifle the use of innovative, evidence-based medicine." ${ }^{.78}$ Prior mandate legislation introduced by the same House Prime Sponsor had been killed in 2016 in the Senate, and similar bills had been introduced as far back as 2004, according to committee analysis. $^{79}$

As one article on the bill noted:

All newborns in California receive a hearing status screening through the California Newborn Hearing Screening Program. Yet upon finding out their child's hearing status, parents are often stunned to find out that interventions and related services are not covered by their health insurance.

74. E-mail from Sheila Tallman, Senior Manager, Premera Blue Cross, to Christine Rolfes, Senator, Washington Senate (Jan. 21, 2016, 20:54 PST) (on file with author). In Washington, the state's elected insurance commissioner did not require insurers to provide autism benefits to children until a unanimous Washington Supreme Court decision; in a suit brought against an insurer, the court directed the commissioner to do so under the plain meaning of long-existing statute. See O.S.T. ex rel. v. BlueShield, 335 P.3d 416, 421 n.9 (Wash. 2014) ("Regence BlueShield's exclusion was contrary to the plain language of the mental health parity act, and OIC's action (or inaction) is irrelevant.").

75. See, e.g., Scott Wilson, Think California Politics Is on the Far-Left Fringe? Just Wait for the Next Elections., WASH. Post (Feb. 3, 2018), https://www.washingtonpost.com/national/thinkcalifornia-politics-is-on-the-far-left-fringe-just-wait-for-the-next-elections/2018/02/04/80e679c205e5-11e8-8777-2a059f168dd2_story.html?noredirect $=$ on\&utm_term $=$. de $82 \mathrm{a} 9 \mathrm{aa} 99 \mathrm{~d} 1$ [https://perma.cc/F2ZU-93UT] ("Here in the self-labeled 'state of resistance,' the political debate is being pushed further left without any sign of a Republican renaissance to serve as a check on spending and social policy ambitions.”).

76. Assemb. B. 1601, 2017 Leg., Reg. Sess. (Cal. 2017).

77. See Assembly Bill Policy Committee Analysis: Hearing on Assemb. B. 1601 Before the Assemb. Comm. on Health, 2017 Leg., Reg. Sess. (Cal. 2017) (statement of Kristene Mapile, Member, Assemb. Comm. on Health).

78. Id. at 6. An organization called Health Access California made its support conditional upon the bill being "amended to extend coverage of hearing aids to adults. According to Health Access, this bill is contrary to the anti-discrimination provision of the ACA based on age.". Id.

79. See id. at 6-7. 
One in ten children in privately funded plans has coverage for hearing aids and hearing aid services, leaving more than 8,000 children without any kind of health insurance coverage for their devices. ${ }^{80}$

California Assembly fiscal staff calculated that passage of the bill would result in no cost to Medicaid, which already covered hearing aids for children, but would produce an increase in "employer-funded premium costs in the private insurance market of approximately $\$ 13$ million" and an increase in "premium expenditures by employees and individuals purchasing insurance of $\$ 6$ million, and reduced out-of-pocket expenses of $\$ 15.5$ million . . . ." ${ }^{\$ 1}$ The bill was killed in the Assembly Appropriations Committee. ${ }^{82}$

Conservative Idaho might be poised to go in a more progressive direction, based upon a House concurrent resolution that passed in 2018, noting that although Medicaid covered hearing aids for Idaho children, private insurance did not. ${ }^{83}$ As the resolution noted, "a child's inability to obtain these devices is not only detrimental to the child's success but also costly to Idaho schools, which must supply special programming to support the learning needs of children who are deaf or hard of hearing[.]" ${ }^{14}$ Accordingly, the Idaho Department of Insurance was directed to consult with insurers on devising a mandate. ${ }^{85}$

As was earlier documented for seniors, untreated hearing disabilities can lead to other costs for children. Representative Anderson, the prime sponsor of the Texas insurance mandate, noted it "will allow children with hearing disabilities to develop at the same pace as their peers and will give them the opportunity to attend traditional classrooms instead of special education classrooms."

For seniors, as Rep. Dingell wrote, "[t]he average American may think Medicare provides for long-term care, but it has real limitations. They would also be shocked to know Medicare does not cover a number of basic needs, such as

80. Bloom 's Hearing Aid Bill Passes Assembly Committee, Park Labrea News \& Beverly PRESS (May 4, 2017), https://beverlypress.com/2017/05/blooms-hearing-aid-bill-passes-assemblycommittee/ [https://perma.cc/DB7C-76XL].

81. Assembly Bill Policy Committee Analysis: Hearing on Assemb. B. 1601 Before the Assemb. Comm. on Appropriations, 2017 Leg., Reg. Sess. (Cal. 2017) (statement of Lisa Murawski, Member, Assemb. Comm. on Appropriations).

82. Bill History, Assemb. B. 1601, 2017 Leg., Reg. Sess. (Cal. 2017), https://leginfo. legislature.ca.gov/faces/billHistoryClient.xhtml?bill_id=201720180AB1601 [https://perma.cc/ YDZ6-URTP]. It was another good session for health insurers. The California Assembly speaker had also killed "single-payer" legislation. See, e.g., Alexei Kosoff, California Nurses and Anthony Rendon Are Still Sparring over Single-Payer Bill, SACRAmento BeE (Jan. 17, 2018, 5:45 AM), https://www.sacbee.com/news/politics-government/capitol-alert/article1 95025409.html [https://perma.cc/7HPV-VRTZ].

83. House Concurrent Res. 45, 64th Leg., 2d Reg. Sess. (Idaho 2018).

84. Id.

85. Id.

86. Anderson, supra note 21. 
hearing aids, glasses, foot care or basic dental." ${ }^{177}$ Those denied access to hearing aids risk being "cut off from community because you cannot hear." 88

As I wrote once, "[i]magine a treatable disability that afflicts tens of millions of Americans and yet is generally uncovered by insurance or Medicare. You would think it would prompt a civil rights uprising." $" 89$

Over a quarter-century ago, the Americans with Disabilities Act declared that "the Nation's proper goals regarding individuals with disabilities are to assure equality of opportunity, full participation, independent living, and economic selfsufficiency for such individual[.."'90 Regrettably, these lofty ideals have not worked out for most who are hearing-impaired. ${ }^{91}$ Are policymakers listening?

87. Debbie Dingell, Aging with Dignity out of Reach for Many in America, DetroIt FreE PRESS (July 11, 2015), https:/www.freep.com/story/opinion/contributors/2015/07/10/retirementlong-term-care/29998343/ [https://perma.cc/9J8J-KSA5].

88. Id.

89. Brendan Williams, Why Are Hearing Disabilities Not Covered by Insurance and Medicare?, THE HILL, (Aug. 5, 2015, 8:00 AM), https://thehill.com/blogs/congress-blog/healthcare/ 250195-why-are-hearing-disabilities-not-covered-by-insurance-and [https://perma.cc/EG8A$\mathrm{UEH} 2]$.

90. Americans with Disabilities Act, 42 U.S.C. § 12101(a)(7) (2018).

91. See Kathleen E. Bainbridge \& Virginia Ramachandran, Hearing Aid Use Among Older United States Adults: The National Health and Nutrition Examination Survey, 2005-2006 and 2009-2010, NAT'L HeAlth Inst. PuB. ACCESS (2015), https://www.ncbi.nlm.nih.gov/pmc/articles/ PMC3999213/pdf/nihms541764.pdf [https://perma.cc/9XLX-SSDL]. There are other discriminatory dimensions too. The low-income and ethnic minorities are particularly disadvantaged. From the study of adults 70 -year-and-older, the authors found, for example, that " $[t]$ he proportion of hearing aid use among non-Hispanic white people was over twice that of nonHispanic black, Hispanic, or other (including multiracial) people ....” Id. at 5. 